\title{
UNIVERSALITY AND COSMOPOLITANISM: SOME INSIGHTS FROM THE WORLD OF MORAL DAMAGE
}

\author{
Merryl Lawry-White ${ }^{*}$
}

\begin{abstract}
This article examines the invocation and application of universal principles regarding reparation for moral damage across three different 'sub-systems' of international law: international human rights law, international criminal law and international investment law. The extensive invocation of certain principles drawn from a state-to-state context, including in scenarios implicating non-state actors, suggests a degree of universality.

Yet, this conclusion is challenged by the variety of approaches taken by bodies constituted under and applying different international law specialisms. The context and mandate of the body in question, as well as the exigencies of particular situations, affect the extent to which universal principles are followed in practice. The considerations underlying the form and standard of reparation, and the ultimate outcome, for example, serve to demonstrate some of the tensions between universality and cosmopolitanism.

There is a growing focus on reparation as a modality and mechanism of justice. The effectiveness of reparation in this role is tied to the extent to which it responds to claimants/petitioners/victims' needs. While universality may play a role in inter alia promoting certainty and conserving resources across a varied international law landscape, a strict approach may undermine the responsiveness of reparation as a measure of justice in different sub-systems and thus of the value of a more cosmopolitan world that opens up avenues for redress for a variety of identities.
\end{abstract}

\section{Keywords}

State responsibility, reparation, international criminal law, international human rights law, international investment law, moral damage

\section{Introduction}

As phenomena that drive and reflect the shifting landscape of international law, universality and cosmopolitanism ${ }^{1}$ are often seen as mutually-reinforcing in

\footnotetext{
International Court of Justice, Judicial Assistant to the Vice-President. The author is grateful for Cecily Rose's comments on an earlier draft of this article and for the assistance of the members of the CJICL editorial team.

1 As defined for the purposes of the conference: http://cjicl.org.uk/conference-registration/ [accessed 6 November 2014].
}

Copyright $\odot$ the Author(s).

This work is licensed under a Creative Commons Attribution-NonCommercial-NoDerivs 3.0 License. 
'stepping away from the state'. However, this contribution notes that they may also act in tension.

Universality conceives of principles as applicable across different 'subsystems' of international law-'sub-systems' that promote cosmopolitanism. Principles require flexibility and adaptability if they are to be applied to a variety of 'clients', by a multitude of dispute resolution bodies, and, at times, through the spectrum of different philosophies, i.e. if they are to be applied within the current international law framework that reflects and facilitates a more cosmopolitan landscape. However, even where they exhibit flexibility, universal principles may not always be appropriate in the circumstances or pertinent to the challenges faced by a specific sub-system.

There is a growing focus on reparation as a modality and mechanism of justice. $^{2}$ A large number of instruments regarding reparation, remedy and redress have been adopted at the international level over the last two decades, many relating to specific sub-sets of international law or particular groups of victims. The 2001 ILC Draft Articles on the Responsibility of States for Internationally Wrongful Act (ILC Articles), ${ }^{3}$ on the other hand, codify widely-accepted 'secondary rules' of international law. ${ }^{4}$ This incorporates the legal consequences that flow from the breach of an international obligation, and thus principles regarding reparation. While these principles have been drawn largely from a state-to-state context, they are invoked in the conceptualisation and realisation of reparation across different 'branches' of international law, including in scenarios implicating non-state actors-a picture suggesting a degree of universality.

However, the principles codified in the ILC Articles are to be applied subject to any applicable lex specialis; they can be excluded within a sub-system or in a specific dispute. ${ }^{5}$ Their universality thus arises from their position as default or 'residual' rules. ${ }^{6}$ Any claim to universality will depend upon the frequency of invocation and the extent to which principles relied upon within each sub-system are based upon these norms. The general nature of the principles codified

\footnotetext{
2 With the caveat that 'justice' has been ascribed many different meanings and some more restrictive definitions may not view reparation as a form of 'justice'.

3 The ILC Draft Articles on the Responsibility of States for Internationally Wrongful Acts, ILC Ybk 2001/II(2), 26.

${ }^{4}$ Commentary to the ILC Draft Articles on the Responsibility of States for Internationally Wrongful Acts, ILC Ybk 2001/II(2), 31, para 1 (ILC Articles Commentary).

${ }^{5}$ ILC Articles, Art 55.

${ }^{6}$ ILC Articles Commentary, Art 55, para 2.
} 
in the ILC Articles, along with the fact that many primary norms are created without specifying the consequences of breach, suggests these principles will be invoked frequently. However, a change in practice as a result of particularised principles within a 'sub-system' would challenge this position and potentially, in turn, contribute to an erosion of the possible contexts in which customary status may be claimed.

This paper examines aspects of the interaction between universality and cosmopolitanism, from the perspective of reparation for non-pecuniary damage (or moral damage). Focusing on the application of customary principles relating to reparation across three 'sub-systems'-international human rights law, international criminal law and international investment law-this paper examines the challenges posed to and questions raised by universal application. These challenges may, however, play an important role in promoting cosmopolitanism, as both an institutional and a moral imperative. If reparation is to form a measure of justice, its effectiveness is tied to the extent to which it responds to claimants/petitioners/victims' needs. Strict universality may therefore undermine the value of a cosmopolitan world that opens up avenues for redress for a variety of identities.

A note on terminology: with the increasing focus on reparation, the term has taken on different connotations in a variety of contexts. Reparation is generally afforded a broad definition and this paper will do the same, using the term in the manner referred to in the ILC Articles, as referring to various acts, goods or other manifestations employed to repair a victim of an internationally wrongful act. ${ }^{7}$ The term moral damage is also employed to describe different concepts, including across national legal systems. What qualifies as non-material or non-pecuniary damage is not always clear and this feeds into the discussion of how different tribunals conceive reparation in light of their respective mandates. The same harm may have pecuniary and non-pecuniary aspects, for example, disruption of education or damage to reputation.

\section{The starting point}

The starting point is the principle common to all branches of international law discussed in this paper: that breaches of international law have consequences. As famously articulated by the Permanent Court of Justice (PCIJ) in the Chorzów Factory ('a passage [...] which has been cited and applied on many occasions') ${ }^{8}$ : '[i]t

7 ILC Articles Commentary, Art 34, paras 1-2 and 6.
8 ILC Articles Commentary, Art 31, para 1. 
is a principle of international law that the breach of an engagement involves an obligation to make reparation in an adequate form. ${ }^{9}$ This customary principle is foundational to upholding the rule and value of international law.

The PCIJ emphasised that, not only this principle, but, by definition, a standard, is inherent within the notion of illegality, and specified the forms of reparation that may be suitable to reach this standard. Conceiving of reparation as a corollary of an illegal act underpins the increasing importance assigned to reparation as a form of justice:

The essential principle contained in the actual notion of an illegal act [...] is that reparation must, as far as possible, wipe out all the consequences of the illegal act and re-establish the situation which would, in all probability, have existed if that act had not been committed. Restitution in kind, or if this is not possible, payment of a sum corresponding to the value which restitution in kind would bear; the award, if need be, of damages for loss sustained which would not be covered by restitution in kind or payment in place of it-such are the principles which should serve to determine the amount of compensation due for an act contrary to international law. ${ }^{10}$

The availability of reparation for moral damage has long been recognised in international law. The 1924 Opinion in the Lusitania Cases (Lusitania), ${ }^{11}$ issued five years before the Chorzów Factory judgment, was one of the earliest international law decisions to address the issue. The Umpire stated that non-material damages are 'very real, and the mere fact that they are difficult to measure or estimate by money standards makes them no less real and affords no reason why the injured person should not be compensated.' ${ }^{2}$ He defined in broad terms the scope of harm for which moral damages could be awarded as, so long as the harm was 'real and actual, rather than purely sentimental and vague': ${ }^{13}$

That one injured is, under the rules of international law, entitled to be compensated for an injury resulting in mental suffering, injury to his feelings, humiliation, shame, degradation, loss of social position or injury to his credit or to his reputation, there can be no doubt $[\ldots]^{14}$

\footnotetext{
${ }^{9}$ Case concerning the Factory at Chorzów (Germany v Poland) (Claim for Indemnity) (Jurisdiction) (1927) PCIJ Ser A No 9, 21 (Chorzów Factory).

${ }^{10}$ Ibid, 47.

${ }^{11}$ Opinion in the Lusitania Cases (1924) 7 RIAA 32.

${ }^{12}$ Ibid, 40.

${ }^{13}$ Ibid, 37.

${ }^{14}$ Ibid, 40.
} 
Further, following the Umpire's examination of national legal systems and 'reparation by equivalent', he noted: '[s]peaking generally, that remedy must be commensurate with the injury received', i.e., assessed on an objective basis.' ${ }^{15}$

These principles are echoed in the ILC Articles. Article 31 emphasises that a state has a duty to make full reparation for material or moral damage caused by the internationally wrongful act of that state, where moral damage includes such things as individual pain and suffering, loss of loved ones or personal affront associated with an intrusion on one's home or private life. ${ }^{16}$ The ILC Articles envisage full reparation as encompassing three modalities and prescribe a hierarchy among them: compensation is available where restitution is not possible or disproportionate and where damage is 'financially assessable'; and satisfaction is available where restitution and compensation cannot reach the standard prescribed by international law to 'wipe out the consequences' of the illegal act-it is an extraordinary or residual form. ${ }^{17}$ The ILC Articles recognise that a combination of two or all forms of reparation may be required to meet the standard that they prescribe. ${ }^{18}$ In line with their general nature, they thus envisage a degree of flexibility depending upon the nature and scope of the damage.

The Commentary to the ILC Articles provides some guidance regarding the standing of moral damage in this analysis. While noting that 'material and moral damage resulting from an internationally wrongful act will normally be financially assessable ${ }^{19}$ and thus appurtenant to compensation, the Commentary distinguishes between non-pecuniary damage to a state and that 'associated with actual damage to property or persons. ${ }^{20}$ The latter appears to encompass the types of harm discussed by the Umpire in Lusitania. The former may be an 'affront' or damage a state's honour and dignity, often an injury of 'symbolic character' resulting from the mere fact of the breach and difficult to value in monetary terms. Moral damage caused to a state is, according to the ILC Articles, more suited to a remedy of satisfaction, which, in itself, may take the form of a monetary payment. ${ }^{21}$ Unlike compensation, however, there is no requirement that such payment be commensurate with the loss. The function of such a

\footnotetext{
${ }^{15}$ Ibid, 35.

${ }^{16}$ ILC Articles Commentary, Art 31, para 5.

${ }^{17}$ ILC Articles, Arts 34-7.

${ }^{18}$ ILC Articles, Arts 34-7.

19 ILC Articles Commentary, Art 37, para 3.

${ }^{20}$ Ibid, Art 36, para 1.

${ }^{21}$ Ibid, Art 37, para 3.
} 
payment is distinct.

This guidance has led to questions about the clarity of the position of compensation for non-economic injury within the framework created by Articles 34 to $37^{22}$ However, as explained above, the framework created by the articles seeks to sub-divide a broader category in light of the different forms of harm that are termed moral damage. Compensation is envisaged as being employed in a mechanical, objective fashion and thus is inappropriate as a remedy for consequences unsuited to quantification (rather than one that is difficult to quantify, as per Lustania). The injury suffered as a result of the fact of a breach is not necessarily speculative, but can be unquantifiable in numerical terms. An analogy can be drawn with injury suffered in a human rights context, where violations of a victim's rights can send an implicit message about a victim's value, dignity and place in the community, regardless of other consequences flowing from the breach. The distinction set out in the ILC Articles may thus prove valuable across different sub-systems.

The principles codified in the ILC Articles discussed above, as a reflection of customary international law, therefore exhibit flexibility and a recognition that: (i) the nature and scope of injury, and (ii) the subject or rights-holder in question will affect the contours and substance of the reparation that is appropriate. The flexibility exhibited in the ILC Articles is a gesture towards universality and an aspiration that the principles will find utility in the many contexts in which they could be employed.

\section{An increasingly cosmopolitan framework}

Traditional norms regarding reparation reflect a system in which international wrongs were conceptualised within a state-to-state framework. Although an individual could be directly harmed by another state, only a state had the right to espouse a claim in respect of this wrong on the international plane: '[q]uiconque maltraite un citoyen offense indirectement l'état qui doit protéger ce citoyen'. ${ }^{23}$ With the codification of customary international law of armed conflicts, for example, a state could be held responsible for physical harm to protected combatants or civilians or damage to civilian property, but only the state of nationality could

\footnotetext{
${ }^{22}$ See discussion in M Parish, A Newlson and C Rosenberg, 'Awarding Moral Damages to Respondent States in Investment Arbitration' (2011) 29(1) Berkeley JIL 225, 229.

${ }^{23} \mathrm{E}$ de Vattel quoted in M Bassiouni, 'International Recognition of Victims' Rights' (2006) 6 HRLR 203, 212 .
} 
request reparation. Between 1794 and 1970, claims regarding the treatment of aliens made up 261 out of 435 claims procedures established, often focusing on harm caused to individuals during a civil war. ${ }^{24}$ Customary international law rules on reparation developed in this context: the state was the victim, either in itself, or as the espouser of the claim of its national.

The proliferation of inter alia international investment treaty tribunals, human rights bodies and courts, international fact-finding bodies, international criminal tribunals and other transitional justice mechanisms established within an international framework has changed the way in which justice is accessed at an international level. However, this change is not universal and the position can be overstated: there are still many natural and legal entities that do not have access to specialised tribunals to claim reparation for breaches of international rights. The European Court of Human Rights $(E C t H R)$ is the only regional human rights court that allows petitions directly from individuals. The fora available for different entities to claim for breaches of international humanitarian law are limited. Investment treaty protection is dependent upon an applicable treaty, including qualification under that treaty, and sufficient funds to pursue arbitration (although the proliferation of third party funders may affect the weight of this factor).

Although the ILC Articles are framed in terms of international obligations of states vis-a-vis other states, the ILC Articles Commentary on Article 33 acknowledges the varied nature of the legal order that the principles target. It notes that, even though the international obligation that forms the subject of the breach, and thus the obligation to make reparation, is owed to another state, the holders of the relevant rights may have a different identity. The breach of a human rights treaty, for example, wrongs the other state parties, but the ultimate rights holder and object of the breach is an individual. The ILC Articles Commentary refers to the International Court of Justice (ICJ)'s recognition in La Grand of individual rights under international law. ${ }^{25}$ This position was also touched on by the ICJ in Diallo, a claim brought in the exercise of diplomatic protection by Guinea against the Democratic Republic of Congo (DRC), in which the ICJ found that the DRC had breached inter alia the International Covenant on Civil and Political Rights (ICCPR) and the African Charter on Human and Peoples' Rights. The ICJ recalled that 'the sum awarded to Guinea in the exercise of diplomatic

\footnotetext{
${ }^{24}$ M Stuyt, Survey of International Arbitrations 1794-1970 (1939) quoted in C McCarthy, Reparations and Victim Support in the International Criminal Court (2014) 12.

${ }^{25}$ ILC Articles Commentary, Art 33, para 3. See La Grand (Germany v US), ICJ Reports 2001 p 466.
} 
protection of Mr Diallo is intended to provide reparation for the latter's injury'. ${ }^{26}$

Similarly, the Ethiopia-Eritrea Arbitration Commission noted its confidence that 'funds received in respect of their claims will be used to provide relief to their civilian populations injured in the war. ${ }^{27}$ However, these funds were limited, especially when compared to the length of the war and multitude of victims. ${ }^{28}$ The victims were dependent upon the states distributing the compensation received. The application of principles regarding reparation within a state-to-state context and thus reliance thus potentially limited the scope of relief available to many of the individual victims and did not specifically address the needs of the ultimate objects of the breach.

Arguments that the principles set out in the ILC Articles apply only to inter-state relations have been rejected. ${ }^{29}$ Materials on the ILC Articles charting their application contain multiple references to bodies concerned with disputes that involve participants other than states, particularly human rights bodies and investment treaty tribunals. The ILC Articles thus acknowledge the wide range of contexts in which their claim to universality will be tested. Practice shows that the institutional framework in which reparation is considered affects the application of these principles and the priority and feasibility assigned to various forms of reparation. There can be key differences at the point of implementation, posing another layer of challenges to claims of universality.

\section{International human rights}

As discussed above, international human rights law is based upon a different structure to that in which international law principles have traditionally found application. Firstly, the obligations are not of a bilateral nature but are owed

\footnotetext{
${ }^{26}$ Ahmadou Sadio Diallo (Republic of Guinea v Democratic Republic of Congo), Compensation, ICJ Reports 2012 pp 324, 344 (Diallo).

${ }^{27}$ See e.g. Eritrea-Ethiopia Claims Commission: Final Award (Eritrea's Damages Claim) (2009) 26 RIAA 505.

${ }^{28}$ The arbitration effectively resulted in net damages to Ethiopia of just over USD 13 million, and USD 2 million to Eritrea for individual claimants. D Hollis, 'Eritrea-Ethiopia Claims Commission Awards Final Damages' (Opinio Juris, 19 August 2009) <http://opiniojuris.org/2009/08/19/eritrea-ethiopia-claims-commission-awards-final-damages/> [accessed 1 August 2014].

${ }^{29}$ See e.g., T van Boven, Introductory Note to 'The United Nations Basic Principles and Guidelines on the Right to a Remedy and Reparation for Victims of Gross Violations of International Human Rights Law and Serious Violations of International Humanitarian Law' (United Nations, 2010) para 2(a), <http://legal.un.org/avl/pdf/ha/ga_60-147/ga_60-147_e.pdf> [accessed 1 August 2014].
} 
erga omnes-the other parties to human rights treaties are all wronged upon breach. ${ }^{30}$ Secondly, as discussed above, and as recognised by the ECtHR in its recent decision in Cyprus $v$ Turkey in the context of an inter-state claim, ${ }^{31}$ the ultimate object of a breach, and the primary victim, is an individual.

It is in this framework that jurisprudence on remedies for non-pecuniary injury has recently developed: with the individual, and not the state, as the petitioner. There are multiple judicial/non-judicial bodies that now have the ability (subject to state consent) to receive applications from individuals in respect of different treaties, for example, the Human Rights Committee in respect of the ICCPR. However, few bodies have the power to issue opinions or judgments that are binding on states. Each body or court has developed its own jurisprudence or recommendations on reparations within the confines of its own jurisdiction. The powers of different regional courts in respect of reparation, for example, are moulded by the relevant lex specialis or constituting treaty. Yet all of them rely on the fundamental principle of international law as set out in the Chorzów Factory case, that a breach of international law entails consequences and a duty to make reparation. ${ }^{32}$ Given the limited space, only ECtHR and Inter-American Court of Human Rights $(I A C t H R)$ jurisprudence is specifically referred to below; the latter in particular given that the IACtHR has developed 'perhaps the most comprehensive legal regime on reparations developed in the human rights field of international law. ${ }^{33}$

The systematic characteristics of a human rights regime provide a rationale for departing from some of the reparations principles codified in the ILC Articles. First, the reparations ordered have a dual focus. A breach is conceived of

\footnotetext{
${ }^{30}$ See D Shelton, Remedies in International Human Rights Law ( $2^{\text {nd }}$ edn, 2005) 97-99.

${ }^{31}$ Cyprus v Turkey (Just Satisfaction) [2014] ECtHR App 25781/94, para 46. For a more detailed discussion of the importance and content of this judgment see, e.g., E MacKenzie, 'European Court of Human Rights Orders Turkey to Pay Cyprus EUR 90,000,000' (ASIL Blog, 15 May 2014) <http://www.asil.org/blogs/european-court-human-rights-orders-turkeypay-cyprus-\%E2\%82\%AC90000000-may-12-2014> [accessed 1 August 2014]; A Risini, 'Can't get no just satisfaction?' (CJICL Online, 23 May 2014) <http://cjicl.org.uk/2014/05/23/cant-getjust-satisfaction-cyprus-v-turkey-judgment-european-court-human-rights/> [accessed $1 \mathrm{Au}-$ gust 2014]. See also F Kollmar \& J M Hoffmann, 'Less Complaints, More Satisfaction: Cyprus $v$ Turkey' (2014) 3 CJICL (in press).

${ }^{32}$ See e.g., UN Human Rights Committee, General Comment No 31: Nature of the General Legal Obligation on States Parties to the Covenant, UN Doc CCPR/C/21/Rev.1/Add.13 (29 March 2004) para 16.

${ }^{33}$ C Grossman (ed), 'Conference on Reparations in the Inter-American System: A Comparative Approach ' (2006-2007) 56 American ULR 1375, 1376.
} 
as a violation of both individual rights and the legal order. ${ }^{34}$ Remedies may therefore require structural changes, such as amending a system of laws or even the constitution of a state, state-wide training programmes or the creation of institutions. ${ }^{35}$ The ECtHR emphasised this point by noting that, where the focus is on structural questions of 'public order', and not individual harm, certain available remedies are inappropriate. ${ }^{36}$ Second, there are two dimensions to reparations in this context: they are both procedural and substantive in nature. The procedural dimension has a functional aspect: that without access to a forum, there is no hope for reparation; but, it may also have a substantive consequence, a dignifying effect, tied to recognition. Participation in shaping the remedy is often tied to the extent to which a remedy is satisfactory.

The ECtHR has the power 'if necessary' to award 'just satisfaction', under Article 41 of the European Convention on Human Rights $(E C H R)^{37}$ (an amended version of the original Article 50), unless the internal law of the breaching state allows for full reparation. Early in its existence, the ECtHR recognised that Article 50 was modelled on provisions of inter-state dispute settlement treaties and that it contemplated remedies based on principles of state responsibility, namely cessation of the breach and restitution. Where compliance with the latter was not forthcoming or not possible, compensation and satisfaction were available. $^{38}$ The ECtHR recently echoed this position, noting that Article 41 is derived from principles of public international law regarding state liability, including, upon breach, the obligation to make reparation in an adequate form as set out in the Chorzów Factory case. ${ }^{39}$

The ECtHR has been criticised for its narrow interpretation of Article 50 (subsequently Article 41), in many cases finding that the declaration of wrongfulness or breach contained in its judgement constituted sufficient reparation. ${ }^{40}$ However, in certain cases of non-pecuniary injury, in light of the seriousness of the violation and the extent of harm caused, the ECtHR has decided that the findings in its judgment can only afford limited satisfaction for non-pecuniary injury and has also awarded monetary damages as part of affording just satisfaction-

\footnotetext{
${ }^{34}$ S G Ramirez in Grossman, above n 33, 1429, 1433.

${ }^{35}$ See e.g., The Last Temptation of Christ (Olmedo Bustons et al) v Chile (2001) IACtHR Ser C No 73, para 97ff, pursuant to which Chile modified its constitution to comply with the order of the IACtHR that looked to guarantee freedom of expression to all persons subject to its jurisdiction.

${ }^{36}$ Cyprus v Turkey (Just Satisfaction), paras 43-44.

${ }^{37}$ European Convention on Human Rights, 4 November 1950, 213 UNTS 222.

${ }^{38}$ Shelton, above n 30, 191-192.

${ }^{39}$ Cyprus v Turkey (Just Satisfaction), above n 31, paras 40-1.

${ }^{40}$ Higgins, as quoted in Shelton, above n 30, 195.
} 
valued on an equitable basis. ${ }^{41}$ Such awards are designed to recognise the moral damage caused by breach of the ECHR and to reflect 'in the broadest terms' the severity of damage. ${ }^{42}$ The ECtHR has also ordered specific measures of reparation under Article 13 ECHR, requiring a state to afford an effective remedy, entailing inter alia a thorough investigation and compensation. ${ }^{43}$ The ECtHR thus looks to restitution at a state level, and, where this is not forthcoming has generally relied upon satisfaction as its remedy of choice for individuals.

Article 63(1) of the American Convention on Human Rights ${ }^{44}$ affords the IACtHR a broader jurisdiction to award reparation than that enjoyed by the ECtHR. In the case of breach:

[...] if appropriate, that the consequences of the measure or situation that constituted the breach of such right or freedom be remedied and that fair compensation be paid to the injured party.

Similarly to the ECtHR, the IACtHR has alluded to the universality of the norm discussed above, stating that Article 63(1):

[...] reflects a customary norm that constitutes one of the basic principles of contemporary international law on State responsibility. When an unlawful act occurs, which can be attributed to a State, this gives rise immediately to its international responsibility for violating the international norm, with the consequent obligation to cause the consequences of the violation to cease and to repair the damage caused. ${ }^{45}$

The IACtHR's directions and awards on reparations are detailed and comprehensive. The judgment in Gelman, brought on behalf of victims of torture and disappearances, provides one example. The IACtHR prescribed multiple measures

\footnotetext{
${ }^{41}$ See Selmouni v France (Judgment) [1999] ECtHR App 25803/94, para 123.

${ }^{42}$ Cyprus $v$ Turkey (Just Satisfaction), above n 31, para 56, (referring to Varnava and Others $v$ Turkey [2009] ECtHR Apps 16064/90, 16065/90, 16066/90, 16068/90, 16069/90, 16070/90, 16071/90, 16072/90 \& 16073/90).

${ }^{43}$ See e.g. Aksoy v Turkey (Judgment) [1996] ECtHR App 21987/93, discussed in T van Boven, 'Reparations: a requirement of justice', in Memoria del Seminario: El sistema interamericano de protección de los derechos humanos en el umbral del siglo (1999) 659.

${ }^{44}$ American Convention on Human Rights, 22 November 1969, 1144 UNTS 123.

${ }^{45}$ Serrano-Cruz Sisters v El Salvador (Merits, Reparations and Costs) (2005) IACtHR Ser C No 118, para 134 (Serrano-Cruz Sisters).
} 
that may be characterised as satisfaction, incorporating those aimed at a public acknowledgement of breach, including requesting that Uruguay publish the IACtHR's judgment and make a widely-disseminated public apology. The IACtHR also prescribed a factual investigation regarding the violations, prosecution and punishment 'as a form of reparation of the victims [sic] right to the truth', as well as various other reforms, including that human rights training be instituted for the judiciary. In addition, the IACtHR awarded pecuniary and moral damages. ${ }^{46}$

The framework of analysis envisaged by the ILC Articles regarding the standard and forms of reparation is not always appropriate in the context of human rights abuses. As envisaged by the ILC Articles Commentary, restitution as a form of reparation for non-pecuniary injury may be impossible by virtue of legal encumbrances or circumstances preventing a return to the pre-breach position. ${ }^{47}$ However, in a human rights context, there are other considerations that may make restitution inappropriate, and raise questions as to its primacy as a form of reparation. The status quo ante is often unachievable, particularly in the face of non-pecuniary damage. In Serrano-Cruz Sisters, in which victims had been disappeared, the IACtHR noted that full restitution was impossible. ${ }^{48}$ The purposes of rape, for example, have been compared to those of torture, as including humiliation, degradation and destruction of the person (sense of self). ${ }^{49}$ Relying on legal measures to 'full[y]' repair such consequences is questionable. Further, to suggest that the experience can be 'wiped out' by a legal remedy may, for some victims, constitute evidence that the gravity of their plight is not being taken seriously and thus detract from the reparative effect of recognising the breach.

Depending upon the definition and nature of the violation under consideration, the pre-breach situation may be one in which the victim was subject to other human rights abuses, for example discrimination and marginalisation. Restoration of the status quo ante is thus an unsatisfactory order for a human rights court to make. The Nairobi Declaration on Women's and Girls' Right to a Remedy and Reparation (Nairobi Declaration) articulates this concern:

$[\mathrm{R}]$ eparation must drive post-conflict transformation of sociocultural injustices, and political and structural inequalities that

\footnotetext{
${ }^{46}$ Caso Gelman v Uruguay (Merits and Reparations) (2011) IACtHR Ser C No 221, paras 259-96.

${ }^{47}$ ILC Articles Commentary, Art 34, paras 4 and 9.

${ }^{48}$ Serrano-Cruz Sisters, above n 45, para 135.

${ }^{49}$ Prosecutor v Jean-Paul Akayesu, ICTR-96-4-T (Judgment, 2 September 1998) para 597.
} 
shape the lives of women and girls; that reintegration and restitution by themselves are not sufficient goals of reparation, since the origins of violations of women's and girls' human rights pre-date the conflict situation. ${ }^{50}$

In this context, the IACtHR has developed the concept of transformative reparations. Where violations occur in a situation of structural discrimination, restoration of the status quo ante is not adequate reparation. Reparations should aim to transform the pre-existing situation. ${ }^{51}$

Given the potential disconnect between restoration of the status quo ante and concepts of reparation, rehabilitation has become an important form of reparation for many manifestations of non-pecuniary damage. Rehabilitation aims to restore the physical and mental integrity of the victim. In essence, it consists of providing victims with the necessary material, medical, psychological and social assistance and support. ${ }^{52}$ It is specifically mentioned in Article 14 of the Convention against Torture, ${ }^{53}$ as follows:

Each State Party shall ensure in its legal system that the victim of an act of torture obtains redress and has an enforceable right to fair and adequate compensation including the means for as full rehabilitation as possible.

Tribunals may choose to award the cost of such support, or to simply require that rehabilitation be provided. ${ }^{54}$

Compensation has played an important role in remedying non-pecuniary injury, as noted in Gelman. It also forms an aspect of the IACtHR's concept of proyecto de vida (life plan) articulated in Loayza Tamayo $v$ Peru, which alludes to 'personal fulfilment' of the person. ${ }^{55}$ However, similar concerns to those

\footnotetext{
${ }^{50}$ Nairobi Declaration on Women's and Girls' Right to a Remedy and Reparation (19-21 March 2007) para 3, <http://www.fidh.org/IMG/pdf/NAIROBI_DECLARATIONeng.pdf> [accessed 1 August 2014].

${ }^{51}$ C Sandoval, 'The Inter-American System of Human Rights and Approach', in S Sheeran \& N Rodley (eds), Routledge Handbook of International Human Rights Law (2013) 427, 439.

52 'Implementing Victims' Rights: A Handbook on the Basic Principles and Guidelines on the Right to a Remedy and Reparation' (REDRESS, March 2006) 36 <http://www.redress.org/downloads/publications/Reparation\%20Principles.pdf $>$ [accessed 1 August 2014].

${ }^{53}$ Convention against Torture and Other Cruel, Inhuman or Degrading Treatment or Punishment, 10 December 1984, 1465 UNTS 85.

${ }^{54}$ Shelton, above $n$ 30, 275-6.

${ }^{55}$ Loayza Tamayo v Peru (Reparations and Costs) (1998) IACtHR Ser C No 42.
} 
discussed in respect of restitution apply to compensation as a remedy. Pablo de Greiff highlights that those who intentionally harm others pursue strategies of 'dehumanisation', pointing to certain assumptions about the agency of those harmed. ${ }^{56}$ Monetary compensation cannot rehumanise. ${ }^{57}$ The mothers of one of the men that had been killed in a massacre considered in the El Amparo case emphasised: '[m]y son was not a cow, I don't want money, what is I want is justice'. This is a sentiment often heard in transitional justice contexts: money without truth and reform is blood-money. ${ }^{59}$ Further, where abuses occur on a large scale, compensation commensurate with the loss may be rendered impossible by insufficient resources, and distributing limited compensation awards (in number or amount) may exacerbate tensions and increase marginalisation.

In light of the challenges associated with restitution and compensation, satisfaction-a traditionally exceptional and residual form of reparation-may play an important role. Satisfaction can take multiple forms, for example, symbolic reparations (such as memorials), or as per ECtHR jurisprudence (echoing the ILC Articles Commentary), a declaration of wrongfulness or a judgment. The 'truth' behind the violations is an important form of satisfaction, and, as noted in Gelman, a right in itself. ${ }^{60}$ The recognition and acknowledgement inherent in measures of satisfaction can play an important role in helping to rebuild dignity. Chile's Supreme Decree No 355 establishing the 1990 Truth Commission stated:

$[\mathrm{O}]$ nly the knowledge of the truth will restore the dignity of the victims in the public mind, allow their relatives and mourners to honour them fittingly, and in some measure make it possible to make amends for the damage done. ${ }^{61}$

The hierarchy of modalities of reparation in the framework envisaged by the ILC Articles did not make its way into the United Nations Basic Principles

\footnotetext{
${ }^{56} \mathrm{P}$ de Greiff, 'Theorizing transitional justice', in M Williams, R Nagy and J Elster (ed), Transitional Justice: Nomos LI (2012) 42.

${ }^{57}$ See e.g. A Reiner, 'Children and Reparations', in Grossman, above n 33, 1439.

${ }^{58}$ Case of El Amparo v Venezuela (1995) IACtHR Ser C No 19, referred to by V Krsticevic, in Grossman, above n 33, 1418, 1419.

${ }^{59}$ P de Greiff, 'Justice and Reparations', in P de Greiff (ed) The Handbook of Reparations (2006), 13.

${ }^{60}$ Gelman, above $n$ 45, para 259.

${ }^{61}$ Supreme Decree No 35525 April 1990 (Chile), preamble, para 3, see 'Report of the Chilean National Commission on Truth and Reconciliation', United States Institute of Peace, 2002, 24, <http://www.usip.org/sites/default/files/resources/collections/truth_commissions/Chile90-Report/Chile90-Report.pdf> [accessed 1 August 2014].
} 
and Guidelines on the Right to a Remedy and Reparation for Victims of Gross Violations of International Human Rights Law and Serious Violations of International Humanitarian $\mathrm{Law}^{62}$ (Basic Principles), which were 'adopted and proclaimed' by the United Nations General Assembly in 2005. The Basic Principles are not in themselves binding on states, but they identify 'mechanisms, modalities, procedures, methods' to operationalise existing obligations in respect of redress and reparation. The Basic Principles 'seek to rationalise through a consistent approach the means and methods by which victim's rights can be addressed'. ${ }^{63}$ With the caveat that the Basic Principles relate to 'gross' and 'serious' violations only, they thus provide an interesting point of departure in a study of 'universality' as a consolidated point of reference for norms employed across a field with various bodies that have different jurisdictions and powers in respect of reparations.

The Basic Principles categorise reparation into five different forms, which are not subject to a specific hierarchy: restitution, compensation, rehabilitation, satisfaction and guarantees of non-repetition. No specific formula is prescribed and a degree of flexibility is therefore retained, thus recognising (as per the ILC Articles) that multiple modalities may be required to remedy a breach. Further, reparation is to be 'adequate' and 'effective'; 'proportional' to the gravity of the violation and the harm, rather than relying on the classic international law standard requiring states to 'wipe out all the consequences' of the breach. ${ }^{64}$ As noted above, particularly in the case of serious or gross violations, the latter standard is aspirational.

Where harm has been suffered on a community-wide or group basis, collective reparations schemes can prove more meaningful and ultimately more effective than individual reparations. Individual reparations payments may, for example, undermine community harmony in contexts where the latter was key to recovery and reconciliation. ${ }^{65}$ Recognition of this fact is another point of departure between human rights jurisprudence and general international law; the concept of collective reparations is much better developed in the former.

\footnotetext{
${ }^{62}$ Basic Principles and Guidelines on the Right to a Remedy and Reparation for Victims of Gross Violations of International Human Rights Law and Serious Violations of International Humanitarian Law, GA Res 60/147 (16 December 2005) Annex.

${ }^{63}$ Bassiouni, above n 23, 251.

${ }^{64}$ ILC Articles Commentary, Art 31, para 3.

${ }^{65} \mathrm{~L}$ Magarrell, 'Reparations in Theory and Practice' (International Center for Transitional Justice, 2007) 6, <https://www.ictj.org//sites/default/files/ICTJ-Global-Reparations-Practice2007-English.pdf> [accessed 1 August 2014], regarding indigenous communities in Chile.
} 
However, the Ethiopia-Eritrea Commission, in its discussion of damage to Barentu town, has been seen as affording limited acknowledgement to the existence of a requirement to make reparation for communal harm. ${ }^{66}$ The ECtHR has not acknowledged harm suffered on a collective basis; but the IACtHR has done so, although still envisaging the individuals within the group, rather than the group as such, as the victim(s). In Plan de Sánchez Massacre v Guatemala, the IACtHR recognised the 'collective nature of the damage produced' and awarded collective reparations 'as an important component of the individual reparation [...]. ${ }^{67}$ Whether victims are conceived of as individuals or the group, a community or a region as a whole, transitional justice reparations schemes for breaches of human rights have often relied on collective reparations. The Moroccan L'Instance Equité et Reconciliation, for example, defined, not only individuals, but also communities or regions as victims and therefore potential beneficiaries of reparations. On this basis, they recommended collective reparations as one of the measures to be implemented by a future reparations scheme. The Moroccan community reparations program targets different regions, and includes both symbolic reparations and development projects. $^{68}$

Unlike in most traditional international law situations, the Basic Principles make clear that the identity of the perpetrator does not affect the right to reparation, therefore all victims, including those of violations committed by non-state actors, should be incorporated in any state reparations program. In this (indirect) sense, the international law principles underlying the Basic Principles are applied to breaches by non-state actors. It is also an extension of the famous Velásquez-Rodriguez principle, that a state has a due diligence obligation to prevent, investigate and prosecute, compensate a breach, even where committed by a private actor. $^{69}$

\section{International criminal law}

Historically, questions of victim redress have not fallen within the ambit of international criminal justice processes. Rather, any available redress was found within a national context or that of international state responsibility, where the

\footnotetext{
${ }^{66}$ See McCarthy, above n 24, 124.

${ }^{67}$ Plan de Sanchez Massacre v Guatemala (Merits) (2004) IACtHR Ser C No 105, paras 86 \& 93.

68 'The Rabat Report-The Concept and Challenges of Community Reparations' (International Centre for Transitional Justice, 12-14 February 2009) 26-31, <http://www.ictj.org/sites/default/files/ICTJ-Morocco-Reparations-Report-2009-English.pdf> [accessed 1 August 2014].

${ }^{69}$ Velasquez Rodriguez Case (Judgment) (1988) IACtHR Ser C No 4, para 172.
} 
latter does not distinguish between civil and criminal liability. The Rome Statute recognises the rights of victims of international crimes to seek reparation and provides a mechanism for them to do so. ${ }^{70}$ This represents a shift in approach even since 1993/1994. Although the Security Council Resolutions establishing the International Criminal Tribunal for Rwanda (ICTR) and International Criminal Tribunal for the former Yugoslavia (ICTY) noted the belief that establishing an international tribunal for prosecution of perpetrators of international crimes would 'contribute to ensuring that such violations are halted and effectively redressed,' ${ }^{71}$ the Rules of Procedure and Evidence (RPE) envisaged that victims would seek reparations themselves before national courts. ${ }^{72}$ Restitution was the only form of reparation mentioned in the statutes of these tribunals and this focused on material damage (the return of property and proceeds) rather than non-pecuniary damage. Even then, commentators note that the tribunals have been reluctant to use these powers. ${ }^{73}$ In 2000, the ICTY judges recommended that an international compensation commission be set up for victims, noting that 'reconciliation' and 'the restoration of peace' in the former Yugoslavia required that victims be compensated for their injuries. ${ }^{74}$

The Rome Statute recognises victims as stakeholders in criminal proceedings and outcomes. The Trial Chamber in Lubanga proclaimed ' $\mathrm{t}$ ] he Chamber accepts that the right to reparations is a well-established and basic human right [...]. ${ }^{75}$ Given that the International Criminal Court (ICC) must interpret and apply the applicable law consistently with internationally recognised human rights, and in light of the discussion above, the Trial Chamber thus invoked in an international criminal law context the general principle laid out in the Chorzów Factory case, that a breach of international law entails consequences vis-à-vis the direct (and in this case, indirect) victim(s). It laid the foundation for a potentially significant role for the ICC in 'repairing' victims of crimes within its jurisdiction. Further, as per traditional principles, the Rome Statute distinguishes the role of

\footnotetext{
${ }^{70}$ Rome Statute of the International Criminal Court, 17 July 1998, 2187 UNTS 90, Art 75; Rules of Procedure and Evidence of the International Criminal Court, ICC-ASP/1/3 (Part II-A) (9 September 2002) Arts 94-9.

${ }^{71}$ See e.g. SC Res 995 (8 November 1994) preamble.

${ }^{72}$ See e.g. International Criminal Tribunal for Rwanda Rules of Procedure and Evidence, 29 June 1995, U.N. Doc. ITR/3/REV.1, Rules 105 and 106.

${ }^{73}$ See e.g. C Evans, Reparations for Victims in International Criminal Law (2012).

${ }^{74}$ Letter dated 2 November 2000 from the Secretary-General addressed to the President of the Security Council, UN Doc S/2000/1063 (3 November 2000) 1.

${ }^{75}$ Prosecutor $v$ Thomas Lubanga Dyilo, ICC-01/04-01/06 (Decision establishing the principles and procedures to be applied to reparations, 7 August 2012), para 185 (Lubanga).
} 
penalty provisions and reparation provisions. Therefore reparations under the Rome Statute are concerned with redressing harm, rather than 'punishment and exemplification. ${ }^{76}$

Article 75 of the Rome Statute empowers the ICC to make a reparations award against the convicted person and/or 'where appropriate' through the Trust Fund for Victims (TFV). This suggests that the groundwork is being laid for recognition of collective responsibility to acknowledge and alleviate victims' suffering. The TFV may also use resources collected from sources other than 'those collected from awards for reparations, fines and forfeitures' to provide support to those who have suffered 'physical, psychological and/or material harm' as a result of crimes within the jurisdiction of the ICC, regardless of a conviction. ${ }^{77}$ The TFV estimates that about 42,300 people are currently benefiting from its general assistance. ${ }^{78}$ There is a distinction, however, between projects implemented as reparation, and those conceived of as general (humanitarian or development) assistance. Reparations are a response to violations and tied to an acknowledgment of wrongdoing. ${ }^{79}$

Article 75 charges the ICC with assessing the scope and nature of harm suffered by victims and developing reparations principles and procedures. The Trial Chamber in Lubanga was the first to develop such principles. The Trial Chamber ${ }^{80}$ noted that, in addition to the Rome Statute, the elements of crimes and the ICC Rules of Procedure and Evidence (RPE), it was to consider, where appropriate, 'the applicable treaties and the principles and rules of international law [...]' and general principles, and that the implementation of reparations 'must be consistent with internationally recognised human rights [...]. ${ }^{\prime}$

In formulating principles, the Trial Chamber relied heavily on human rights jurisprudence and repeatedly cited the Basic Principles. It also invoked human rights reports and various non-binding instruments touching upon reparation and redress, including the Nairobi Declaration cited above. This represents a

\footnotetext{
${ }^{76}$ See McCarthy, above n 24, 84.

${ }^{77}$ Regulations of the Trust Fund for Victims, Resolution ICC-ASP/4/Res.3 (3 December 2005) paras 47-8.

${ }^{78}$ See <http://www.trustfundforvictims.org/projects> [accessed 13 April 2014].

${ }^{79}$ See, e.g., United Nations Entity for Gender Equality and the Empowerment of Women, Reparations, Development and Gender (2012) 5, <http://www.unwomen.org/media/Headquarters/Attachments/Sections/Library/Publications/2012/10/06a-Development-Gender.pdf> [accessed 14 October 2014].

${ }^{80}$ Lubanga, above n 75 , paras $182-4$.

${ }^{81}$ Rome Statute, Art 21.
} 
nod towards universality, as principles from one branch of international law are incorporated into another.

The concerns set out above regarding applying the standards and hierarchy of different forms of reparation from traditional international law in a human rights context thus form potential considerations in an international criminal law setting - to a greater or lesser extent in light of the institutional and circumstantial context. The Trial Chamber in Lubanga alluded to many of these concerns in setting out its principles.

Full reparation will in many cases remain aspirational: much of the damage caused by such crimes cannot be wiped out. The Trial Chamber rather confirmed the appropriate standard as that set out in the Basic Principles-that reparations be 'appropriate, adequate and prompt' and proportionate to the harm, injury, loss and damage as established by the ICC. ${ }^{82}$ With respect to resources, the burden of repair is usually beyond what a state could manage under normal circumstances, and building a full picture of the identity of victims and the details and extent of harm suffered was beyond the ICC's resources or capacity. In its submission, the TFV noted that costly reparations proceedings could not be justified in light of limited available funds. ${ }^{83}$ The Trial Chamber noted the 'uncertainty' of the number of victims of Lubanga's crimes, 'save that a considerable number of people were affected' ${ }^{84}$ The United Nations Children's Fund (UNICEF) noted that marginalised victims in Ituri were unlikely to have applied for reparations, whether due to insufficient resources, or a wish to avoid further stigma and discrimination by identifying themselves. ${ }^{85}$

Restitution as a blanket strategy is often ill-suited to the situation of victims of international criminal law violations, particularly where non-pecuniary injury has resulted. The potentially problematic nature of restoring a victim to the pre-breach situation would appear to answer any questions as to whether restitution should be accorded primacy because it is cited first in Article 75. The Trial Chamber stated that restitution would 'often be unachievable for victims of the crimes of enlisting and conscripting children under the age of 15 and using them to participate actively in the hostilities. ${ }^{86}$ The Trial Chamber also stated its intention to 'avoid replicating discriminatory practices or structures that

\footnotetext{
${ }^{82}$ Lubanga, above $\mathrm{n} 75$, paras $242-3$.

${ }^{83}$ Ibid, para 121.

${ }^{84}$ Ibid, para 219.

${ }^{85}$ Ibid, para 38.

${ }^{86}$ Ibid, para 223 (emphasis added).
} 
pre-dated the commission of the crimes' in the implementation of reparations. ${ }^{87}$ Those involved with child protection note that there is an increased likelihood that marginalised children will be recruited as child soldiers. ${ }^{88}$ While restitution may be more appropriate in terms of, for example, pecuniary loss in the form of specific assets, it is questionable to afford it primacy as part of an analytical framework for the purposes of international criminal law.

In respect of compensation, the Trial Chamber's position partially reflected that in the ILC Articles, and relied directly on the Basic Principles. Compensation should be considered where economic harm was 'sufficiently quantifiable', it was 'feasible' given resources and it would be 'appropriate and proportionate'. The type of harm potentially apposite for an award of compensation was defined widely, in accordance with 'internationally recognised human rights law', and included material and moral damage. The logistical difficulties and resource shortages discussed above are equally applicable to the feasibility of 'assessing' and paying for compensation awards, especially given the number of potential victims. As with restitution, the Trial Chamber noted that compensation would be 'considered'-thus affording the discretion to refuse compensation even where harm was financially assessable. Further, it must be appropriate: as noted above, compensation could reinforce prior discriminatory practices. ${ }^{89}$

Article 75 refers to rehabilitation, but makes no mention of satisfaction. The Trial Chamber followed this practice-perhaps as recognition of the need for specific remedial measures that are not covered by restitution or compensation, as well as the fact that a public, reasoned guilty verdict (a form of satisfaction) must, in this framework, have already been issued in order for a victim to qualify for reparation. However, the Trial Chamber confirmed that the forms of reparation listed in Article 75 were not exhaustive and it suggested a number of other measures that qualify as satisfaction and guarantees of non-repetition, including an apology, raising society's awareness of the crimes committed and measures aimed at preventing future conflict. ${ }^{90}$ The Trial Chamber also discussed wide dissemination of the conviction in the case, in terms suggesting it

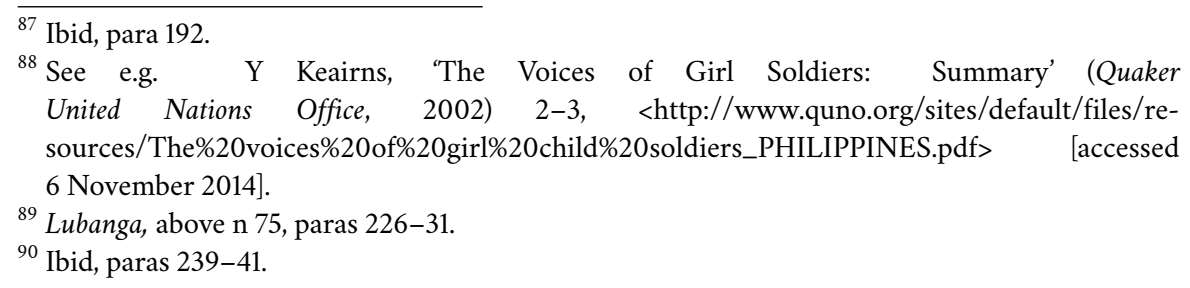


could qualify as satisfaction and a guarantee of non-repetition. ${ }^{91}$

Rehabilitation in this context was to include the provision of medical services and measures to 'facilitate reintegration into society'. Further echoing the IACtHR's jurisprudence on this point, the Trial Chamber referred to the potential 'transformative objectives' of rehabilitation programmes and noted that symbolic reparations could also assist. ${ }^{92}$ By reference to CEDAW and the Nairobi Declaration, the Trial Chamber also accepted that it could prioritise amongst victims, on the basis of vulnerability or urgency of need (medical assistance, care for trauma, etc.) thus apparently affording rehabilitation measures a position of priority in such circumstances. ${ }^{93}$ Although alien to many situations from which the principles underlying the ILC Articles are drawn, the question of prioritising is one facing many bodies that are mandated to deal with non-pecuniary damage to a multitude of victims.

RPE 97 gives the Trial Chamber the option of granting reparation on an individual or collective basis, or both. Like the IACtHR, the Trial Chamber in Lubanga did not conceptualise the group itself as a victim, rather that reparations could be awarded to individual victims or 'groups of victims. ${ }^{94}$ In light of, inter alia, the number of victims, including unidentified victims, and limited resources, the Trial Chamber provided for collective reparations. It emphasised that, wherever possible, reparations should promote reconciliation. It took note of submissions, such as that of the TFV, that individual reparations may undermine the reconciliation process, but that collective reparations may 'foster reconciliation and build trust'. The TFV was concerned that 'community discontent' could lead to victims declining reparations awards. ${ }^{95}$ Further, the ICC looks to prosecute a small number of perpetrators responsible for the most serious crimes (hence the emphasis on complementarity), and thus multiple victims in the scenarios before the ICC will not find 'justice' on the international plane in the sense that the perpetrator of their crimes will not be tried. To exclude them from a reparations award would risk further unbalancing the narrative of the situation written by the judgment and the potential for reconciliation. Collective reparations can help to redress the imbalance and facilitate consistent application of principles across groups of victims.

The procedural aspect of reparation discussed above in relation to human

\footnotetext{
${ }^{91}$ Ibid, para 238.

92 Ibid, paras 232-6.

${ }^{93}$ Ibid, para 200.

${ }^{94}$ Ibid, para 217.

${ }^{95}$ Ibid, paras 44, 57 and 63.
} 
rights law was also emphasised in the Lubanga decision. The Chamber envisaged a consultative phase, allowing all 'victims that may ultimately benefit' to 'express their views and concerns., ${ }^{96}$ Where resources are limited, victims themselves are often best-placed to determine the priorities for allocation. Further, participation engenders a sense of ownership and assists in managing expectations. This rationale mirrors the submission of the TFV that outreach and communication were 'essential to ensure that any reparations award "lives up to its fullest symbolic potential", 97

\section{Investment treaty arbitration}

Reparation for non-pecuniary damage is rarely pleaded in investment treaty arbitration and is even more rarely awarded. In 2008, the tribunal in Desert Line Projects $v$ Yemen (Desert Line) became the second-ever International Centre for Settlement of International Disputes (ICSID) tribunal to award moral damages, i.e. compensation for non-pecuniary damage. ${ }^{98}$ Although not denying their ability to award compensation for non-pecuniary damage, investment treaty tribunals faced with a request for moral damages have exhibited a general reluctance to do so. This section examines the invocation of the principles discussed above and how those standards have been moulded and applied in the investment treaty context.

In 1980, the tribunal in Benvenuti \& Bonfant $v$ Congo became the first ICSID tribunal to award moral damages, in this case approximately two per cent of the amount requested at around USD25,000. ${ }^{99}$ Even though the tribunal decided that the claimants had submitted insufficient evidence of their alleged préjudice moral, the tribunal awarded moral damages on an equitable basis as the illegal actions of the Congolese government had 'certainly disturbed' the claimants' activities. ${ }^{100}$ However, the tribunal was not constituted under an investment treaty. The tribunal awarded moral damages under Congolese law (which it deemed identical to French law in all material respects) and acting ex aequo et bono, pursuant to the agreement of the parties. ${ }^{101}$ As a result, although the award has been invoked to support the premise that moral damages are available

\footnotetext{
${ }^{96}$ Ibid, para 268.

${ }^{97}$ Ibid, para 31.

${ }^{98}$ Desert Line Projects LLC $v$ Yemen, ICSID Case No ARB/05/17 (Award, 6 February 2008) para 291.

${ }^{99}$ Benvenuti \& Bonfant v Congo, Award (1980) 21 ILM 740, para 4.96.

${ }^{100}$ Ibid.

${ }^{101} \mathrm{Ibid}$, paras 4.2-4.3.
} 
in investment treaty arbitration, the discussion of the tribunal has not been frequently relied upon as guidance by subsequent tribunals constituted under treaties and faced with moral damages claims.

The award in Desert Line, on the other hand, has proved more influential. Desert Line brought a claim for breach of the Oman-Yemen bilateral investment treaty $(B I T)$, alleging that Yemen had failed to respect a domestic arbitral award in Desert Line's favour and subsequently adopted various measures to pressure Desert Line to enter into a settlement agreement. These measures included harassment, arrest and intimidation of Desert Line's employees by Yemen and armed tribes. Desert Line claimed moral damages for the resulting stress and anxiety suffered by its executives and for damage to its credit, reputation and prestige. $^{102}$

The tribunal found a breach of the treaty and reaffirmed the proposition set out above that, where caused by the unlawful act of a state, moral damages are available for breach of an international obligation. It noted that moral damages were generally available in most legal systems and concluded that 'there was no reason to exclude' moral damages in the context of investment treaty arbitration, with the following qualification:

Even if investment treaties primarily aim at protecting property and economic values, they do not exclude, as such, that a party may, in exceptional circumstances, ask for compensation for moral damages. ${ }^{103}$

The tribunal did not clarify whether 'exceptional circumstances' was a reference to the characteristics of the system or an element of the standard to be applied to the award of moral damages. The context of the tribunal's comments would suggest the former, given the protections and breaches envisaged and the players involved. The focus on an economic commodity is likely to mitigate against a proliferation of moral damages awards. Many claimants are legal persons and there is a limited range of non-pecuniary damage that a legal person can suffer, for example, damage to reputation. ${ }^{104}$ The latter will often be compensated as part of an award for pecuniary loss. Further, as noted by the Umpire in Lusitania, substantiating non-pecuniary injury can be difficult, ${ }^{105}$ and

\footnotetext{
${ }^{102}$ Desert Line, above n 98, para 286.

${ }^{103}$ Ibid, para 289 (emphasis added).

${ }^{104}$ Ibid.

${ }^{105}$ Lusitania, above n 11, 40.
} 
proving causation may be particularly difficult when the claim is for breach of an investment protection.

The Desert Line tribunal concluded that the breach had been 'malicious' and 'constitutive of a fault-based liability' and that, consequently, Yemen was liable for material and moral damage flowing from the breach. The tribunal did not, however, envisage punitive damages, but quantified damages based on the harm suffered (on an objective basis), thus in line with the principles set out in Lusitania and the ILC Articles. The tribunal inferred that a causative link in respect of moral or material damage may be easier to establish in the presence of aggravating circumstances. $^{106}$

Subsequent tribunals have interpreted 'exceptional circumstances' as applying to the standard for the award of moral damages, requiring either egregious conduct on the part of the state or referring to the nature or extent of harm suffered. The (limited and obiter) comments of the tribunal in Siag are an example of the former. The Siag tribunal referred to the Chorzów Factory case, noting that reparation was compensatory only, but, by reference to Desert Line, seemingly equated the standard for moral and punitive damages as being 'fault-based' when it stated: 'it appears that the recovery of punitive or moral damages is reserved for extreme cases of egregious behaviour.'107

The tribunal in Lemire confirmed that moral damages are available in investment treaty arbitration and could compensate a wide scope of injury. However, following a review of the harm in question and the awards rendered in Desert Line, Lusitania and Siag, the Lemire tribunal concluded that moral damages were available in 'exceptional cases', where inter alia both cause and effect are grave or substantial. ${ }^{108}$ These guidelines appear to set a higher bar than that required by the ILC Articles. However, this may relate to the specific circumstances of the case and the tribunal's concern to avoid double counting. Given the 'significant amount' of compensation awarded in respect of pecuniary damages (based on a discounted cashflow model, which would factor in reputational harm), the tribunal concluded that only 'extraordinary' harm would satisfy a 'separate and additional' award of moral damages. 109

Tribunals presiding over cases in which respondent states have claimed moral

\footnotetext{
${ }^{106}$ Desert Line, above n 98, para 290.

${ }^{107}$ Waguih Elie George Siag $\&$ Clorinda Vecchi v Egypt, ICSID Case No ARB/05/15 (Award, 1 June 2009) paras 544-6.

${ }^{108}$ Joseph Charles Lemire v Ukraine, ICSID Case No ARB/06/18 (Award, 28 March 2011) para 333 (Lemire).

${ }^{109} \mathrm{Ibid}$, paras 333-45.
} 
damages have reached similar conclusions regarding the standard for awarding moral damages. As per the ILC Articles, tribunals faced with claims by states have available to them another reparative formula-that of satisfaction for an 'affront or injury caused by a violation of rights not associated with actual damage to property or persons. ${ }^{\prime 10}$ In practice, like human rights bodies, investment treaty tribunals have also applied this standard in favour of and against non-state actors.

The tribunals in Europe Cement and Cementownia declined jurisdiction over claims against Turkey, noting an 'abuse of process' on the part of the claimants. Turkey requested moral damages for the reputational harm suffered. Although both tribunals noted the availability of moral damages in investment treaty arbitration, they found that 'exceptional circumstances such as physical duress' were required to justify compensation for non-pecuniary injury. ${ }^{11}$

The tribunals considered that the conclusions of their awards, as well as an award of costs (of USD4 million in Europe Cement (which was declared to have a deterrent as well as compensatory objective) and USD3.5 million in Cementownia) constituted sufficient satisfaction. ${ }^{112}$ The tribunals implied that to award compensation for reputational damage would have constituted double counting. The choice of satisfaction as a remedy for reputational damage of a state echoes the conclusion set out in the ILC Articles that injury to the reputation or an 'affront' is more suited to satisfaction, another gesture towards the universality of the principles codified therein. However, commentators have noted that this approach does not take into account the financial consequences of an unmeritorious claim over the course of the proceedings (for example, a detrimental effect on the investment climate). ${ }^{113}$

Like human rights tribunals, investment treaty tribunals have also applied the logic behind satisfaction as a form of reparation to the claims of non-state actors. In Victor Pey Casado and President Allende Foundation v Chile, the tribunal found that the claimant had provided insufficient proof in respect of its moral damages claim, but that, in any case, 'le prononcé de la présente sentence [...] constitue en soi une satisfaction morale substantielle et suffisante.114

\footnotetext{
${ }^{110}$ ILC Articles Commentary, Art 37, para 3.

${ }^{111}$ Europe Cement Investment and Trade SA v Republic of Turkey, ICSID Case No ARB(AF)/07/2 (Award, 13 August 2009) paras 174-5 and 181 (Europe Cement); Cementownia 'Nowa Huta' SA v Republic of Turkey, ICSID Case No ARB(AF)/06/2 (Award, 17 September 2009) paras 159 and 169 (Cementownia).

${ }^{112}$ Europe Cement, above n 111, paras 181 and 185; Cementownia, above n 111, paras 171-2.

${ }^{113}$ Parish, Newlson and Rosenberg, above n 22, 244.

${ }^{114}$ Victor Pey Casado and President Allende Foundation v Chile, ICSID Case No ARB/98/2 (Award, 8
} 
As noted above, investment treaty tribunals thus face a series of challenges when presented with a claim for reparation for non-pecuniary damages. It is 'one of the best settled rules of the law of international responsibility of States' that 'no reparation for speculative or uncertain damages can be awarded. ${ }^{115}$ Yet substantiating moral damages and showing causation-'a logical link between'116 cause and effect (breach of an economic protection and non-pecuniary damage)-may be particularly difficult, given the nature of the norm in question. This could be compared, for example, to the approach taken by the IACtHR of presuming mental pain and anguish where a serious violation has been inflicted upon the victim or family member of the victim. ${ }^{117}$

It is in this context that the emphasis of tribunals on 'exceptional circumstances' may be understood to counter insufficient proof of causation or damage, or to avoid double counting. However, even taking these considerations into account, tribunals have adopted standards that exhibit an apparent reluctance to award reparation for non-pecuniary damage, and particularly compensation. 'Exceptional circumstances' have seemingly become, in theory and practice, an additional limb of the test set out under customary international law norms in order to reflect these complexities as foreseen by tribunals.

\section{Conclusions}

The ILC Articles set out certain fundamental principles related to reparation for breach of international norms. The proposition that their application is limited to situations involving states exclusively has been rejected. The ILC Articles have been relied upon and invoked in many different sub-systems of international law and many different instruments. The Updated Set of Principles to Combat Impunity (Impunity Principles), for example, explicitly rely upon the customary principle as codified in Article 31 of the ILC Articles, that the breach of an international obligation gives rise to an obligation to make full reparation. ${ }^{118}$ The claim of these principles to universality is strong and is bolstered by their general,

\footnotetext{
May 2008) paras 689 and 705.

${ }^{115}$ Southern Pacific Properties (Middle East) Ltd v Arab Republic of Egypt, Award (1992) 32 ILM 933, para 189.

${ }^{116}$ Lemire, above n 108, para 157.

${ }^{117}$ E.g. Maritza Urritia v Guatemala (Merits, Reparations and Costs) (2003) IACtHR Ser C No 103, para 169.

${ }^{118}$ Diane Orentlicher, Report of the Independent Expert to update the Set of Principles to Combat Impunity, UN Doc E/CN.4/2005/102 (18 February 2005) 16 (fn 76-7).
} 
flexible nature and application in situations where non-state actors may have to make reparation.

Yet, at the same time, different sub-systems have developed 'particularised principles to address ways in which the specific forms of harm relevant to their work should be redressed by the responsible party.'19 This paper has only discussed three sub-systems. Yet this has been sufficient to show that the forms and modalities of reparation, the standard of reparation and the harm that may be remedied encompass examples of such particularised principles. The analytical framework established by the ILC Articles was not adopted by the Basic Principles. The primacy of restitution is one illustration of how that framework may be 'inappropriate' in the context of human rights abuses. The concept of transformative reparations was developed to counter the problematic assumption that adequate reparation could be afforded by restoring the status quo ante.

There are many tragic circumstances in which the number of victims, the gravity and nature of harm, or a combination of these elements, make 'wiping out the consequences' unattainable or unfeasible. Yet, this should not imply that the ability to repair should be a mandatory factor in the reparation standard. Nor does a wish to respond to the needs and situation of each victim imply that there should be no standardisation-reinventing the wheel in each case could undermine the system, detracting from certainty, requiring too many resources, etc. Instead, these considerations suggest that there might be space to adopt a different formulation of the standard and a flexible and less hierarchical approach to the forms of reparation available, and to acknowledge the potential importance of often less resource-intensive forms of satisfaction.

As noted above, the invocation of the same principles across different branches of law regularly produce different results, especially at the point of implementation, as illustrated by compensation for non-pecuniary damage. In some cases, this difference can be attributed in part to the nature of the primary norm in question. The damage flowing from stress and anxiety caused to Desert Line's executives, for example, as well as damage to the company's reputation, was valued on a lump sum basis by reference to the 'vastness' of the project, and resulted in USD1 million in moral damages. ${ }^{120}$ Human rights courts, on the other hand, often quantify compensation on an 'equitable basis. ${ }^{121}$ In Diallo, the

\footnotetext{
${ }^{119}$ See McCarthy, above n 24, 132.

${ }^{120}$ Desert Line, above n 98, para 290.

${ }^{121}$ Diallo, ICJ Reports 2012 p 324.
} 
ICJ stated '[q]uantification of compensation for non-material injury necessarily rests on equitable considerations'. It awarded Guinea USD85,000 in respect of the non-pecuniary damages suffered by Mr Diallo. ${ }^{122}$ In his Declaration, Judge Greenwood noted that the sums awarded in respect of moral damages by 'other international courts and tribunals, especially the main human rights jurisdictions [...] are usually quite small'. He referred to, for example, the IACtHR's compensation award of USD100,000 in Gutierrez-Soler v Colombia ${ }^{123}$ 'to a man who had been tortured into signing a false confession, persecuted for an offence he had not committed and separated from his family for so long that he lost all contact with his child for several years.' ${ }^{124}$ One might also consider the ECtHR's award in Mikheyev $v$ Russia of $€ 120,000$ compensation for non-pecuniary losses (loss of amenity). The applicant was paralysed as a result of severe torture at the hands of the police. The paralysis would affect his ability to work, to have children and to live without assistance. ${ }^{125}$

The Diallo judgment illustrates another development arising from and shaping the application of universal principles in a cosmopolitan structure. The ICJ, operating in a diplomatic protection context, surveyed the application of reparations principles in respect of human rights breaches across different sub-systems (namely arbitral tribunals and regional human rights courts) and drew upon the results in its findings. This enhances the claim to 'universality' of principles, based upon those codified in the ILC Articles, but that have been developed and particularised within a specific sub-system in respect of a type of protection and a particular subject. Given that access to international enforcement mechanisms is limited for many international law rights holders (as discussed above), this development may contribute to ensuring that reparation in a diplomatic protection context is responsive from the point of view of the ultimate rights holder. It also suggests a re-thinking of the interrelationship between universality and cosmopolitanism, as generalised principles may become particularised within a specific sub-system and then applied by fora across different 'branches' of international law based on a particular specialisation.

\footnotetext{
${ }^{122}$ Ibid, 391, 394 (Judge Greenwood, sep op).

${ }^{123}$ Gutiérrez Soler v Colombia (Judgment) (2005) ICtHR Ser C No 132.

${ }^{124}$ Diallo, ICJ Reports 2012 pp 324, 391, 394 (Judge Greenwood, sep op).

${ }^{125}$ Mikheyev v Russia [2006] ECtHR App 77617/01, para 163.
} 